\title{
Perception of the nursing staff about the nurse's role in the emergency service
}

\author{
Percepção da equipe de enfermagem sobre a função do enfermeiro no serviço de \\ emergência
}

\section{Percepción del personal de enfermería sobre el papel del enfermero en el servicio de emergencia} Mayckel da Silva Barreto ${ }^{1},{ }^{2}$, , Elen Ferraz Teston ${ }^{1}$, Jamilly Grava Miranda ${ }^{1}$, Guilherme de Oliveira Arruda ${ }^{1}$,
Elizabeth Amancio de Souza da Silva Valsecchi ${ }^{1}$, Sonia Silva Marcon $^{1}$

\begin{abstract}
Objective: to know the perception of the nursing staff about the nurse's role in emergency service. Methods: descriptive study of a qualitative approach. 30 nursing professionals participated and were active in a unit of Emergency. The data were subjected to Content Analysis, thematic modality. Results: the interviewees highlighted as nurses functions, the development of management activities; the leadership and supervision of nursing staff; and the care provided to seriously ill patients. From the perspective of nursing technicians, management activities receive great attention from nurses, rather than direct patient care. However, for nurses, managerial functions and leadership and supervision of staff converge for quality care. Conclusion: the importance of care work of nurses in emergency situations is perceived both by nursing technicians and by nurses. However, perceptions of their role as a manager still show up conflicting.
\end{abstract}

Descriptors: Nursing, Team; Professional Role; Emergency Medical Services; Emergency Service, Hospital; Emergency Nursing.

Objetivo: conhecer a percepção da equipe de enfermagem acerca da função do enfermeiro no serviço de emergência. Métodos: estudo descritivo, de abordagem qualitativa. Participaram 30 profissionais de enfermagem atuantes em uma unidade de Pronto Atendimento. Os dados foram submetidos à Análise de Conteúdo, modalidade temática. Resultados: os entrevistados destacaram como funções dos enfermeiros o desenvolvimento das atividades gerenciais; a liderança e supervisão da equipe de enfermagem; e o cuidado prestado ao paciente gravemente enfermo. Sob a ótica dos técnicos em enfermagem, as atividades gerenciais recebem grande atenção dos enfermeiros, em detrimento da assistência direta aos pacientes. Contudo, para os enfermeiros, as funções gerenciais e a liderança e supervisão da equipe convergem para um cuidado de qualidade. Conclusão: a relevância do trabalho assistencial do enfermeiro nas situações emergenciais é percebida tanto por técnicos em enfermagem, quanto por enfermeiros. Porém, as percepções acerca da sua função como gerente ainda mostram-se conflitantes.

Descritores: Equipe de Enfermagem; Papel Profissional; Serviços Médicos de Emergência; Serviço Hospitalar de Emergência; Enfermagem em Emergência.

Objetivo: conocer la percepción del personal de enfermería sobre el papel del enfermero en el servicio de emergencia. Métodos: estudio descriptivo, cualitativo. Participaron 30 profesionales de enfermería que trabajan en una unidad de Pronta Asistencia. Datos sometidos a análisis de contenido, modalidad temática. Resultados: encuestados destacaron como funciones de enfermeros el desarrollo de actividades de gestión; dirección y supervisión del personal de enfermería; y atención prestada a pacientes gravemente enfermos. Bajo la perspectiva de los técnicos de enfermería, actividades de gestión reciben gran atención por parte de enfermeros, en lugar de atención directa al paciente. Pero, para los enfermeros, las funciones de gestión, liderazgo y supervisión del personal convergen para atención de calidad. Conclusión: la importancia del trabajo de atención de enfermería en situaciones de emergencia es percibida tanto por técnicos de enfermería cuanto por enfermeros. Sin embargo, las percepciones acerca de su papel como entrenador aún aparecen en conflictos.

Descriptores: Grupo de Enfermería; Rol Profesional; Servicios Médicos de Urgencia; Servicio de Urgencia en Hospital; Enfermería de Urgencia.

\footnotetext{
${ }^{1}$ Universidade Estadual de Maringá. Maringá, PR, Brazil.

${ }^{2}$ Faculdade de Filosofia, Ciências e Letras de Mandaguari. Mandaguari, PR, Brazil.

${ }^{3}$ Faculdade Intermunicipal do Noroeste do Paraná. Loanda, PR, Brazil. 


\section{Introduction}

The urgent and emergency services have peculiarities and specialties that have been studied in various parts of the world ${ }^{(1-3)}$. A special focus has been given to the increased demand and use of this health care level, which has influenced the emergence of problems related to infrastructure, service organization, care quality, quantity and specificity of care provided and overload of the work staff ${ }^{(1)}$.

In Brazil, the emergency units are an entry point for most users in the public health system. Even today we can see a reversal in the care flow between primary health care and high complexity services ${ }^{(4)}$. Thus, the assistance provided in the emergency department necessarily involves the screening and referral of a portion of the demand of patients to other health services, overburdening the professional staff and disorganizing the service in the sector ${ }^{(5)}$.

It is important to emphasize that these units were constituted as challenging workplace for health professionals, especially for members of the nursing staff, who make up most of the workforce in the sector, as well as live with overcrowding, disorganization and administrative bureaucracy, must attend a demand for cases of intense gravity and unpredictability, which triggers constant stress ${ }^{(1)}$.

Given these notes, it is presupposed that the patient care performed by the nursing staff, especially by the nurse, is directly influenced by the current characteristics of the sector service and also by the diverse performed activities ${ }^{(6-7)}$. In nursing services, one of the main functions of the nurse is management, in which is imbricated to the assignment of work organization and involved human resources ${ }^{(8)}$. Therefore, the nurse makes use of planning, staff sizing, continuing education, the delegation of activities, staff supervision, performance evaluation and physical, material and financial resources ${ }^{(9)}$.

In this regard, the nurse is the main responsible for the organization of their staff work process, especially regarding the management of nursing actions focused on quality of care. It is worth noting that the whole care process requires planned, structured and continuous actions, to subsidize the humane and resolute care. Thus, the nurse should seek ways to perform nursing management with a focus on patient needs, combining the goals of their staff and also the organization of the work process ${ }^{(9)}$.

Thus, the work of nurses in the emergency department involves specificities and necessary articulations indispensable to care management, requires scientific improvement, technological management and extensive humanization for family members, with significant representation in this professional work process, assuming importance not only because of the complexity and specificities of actions on care, but also for the used material and human resources, and the need to interface with other sectors of the hospital and the local health system ${ }^{(10)}$.

This study is justified by the important work of nurses in the emergency department and the increasing need for adequacy of multidisciplinary work, and especially nursing, in these sectors, which will be essential to recognize the specific function of each professional by the staff members ${ }^{(7)}$. However, it was only found studies that evaluated the role of nurses in emergency situations from the perspective of patients ${ }^{(11-12)}$ and nurses ${ }^{(13)}$, without considering the perception of the nursing staff, as a whole. Thus, the following question arises: Which is the perception of the nursing staff about the nurse's role in the emergency department? To answer it outlined as the objective of this study: to know the perception of members of the nursing staff about the nurse's role in emergency service.

\section{Method}

This is a descriptive study of qualitative nature, performed by the nursing staff active in the Emergency Department of a teaching hospital of medium size, located in southern Brazil.

The hospital has 123 beds and is a reference to 
the urgency and emergency service for the Northwest of Paraná State. The average of daily attendance is 150 patients and increased on weekends. For structural organization effect the Emergency Department is divided into five sections with a total of 36 beds, which are: emergency room (four beds); semiintensive care unit (four beds); inpatient ward/ adults observation (eighteen beds); admission room/ teenagers observation (two beds) and pediatric observation room (eight beds). The nursing staff in the sector, at data collection time, was composed of 70 professionals, 21 nurses and 49 nursing technicians.

It is noteworthy that in the Emergency Department, the nursing staff professionals work in monthly rotation scheme, so they act and know the routine of each of the sectors of the care unit. Thus, even though the focus of this study is the work of nurses in the Emergency Room, all professionals working in the Emergency Department were eligible to participate in the investigation, since they knew the routines and the work of nurses in this particular sector.

Data were collected between April and July 2013, through individual interviews, performed in a private room in the hospital, with 30 professional of nursing staff, working in three shifts (morning, afternoon and night), selected by convenience.

The interviews were performed during the work period of the participants. The interviews were recorded on digital media, lasted an average of fifteen minutes and were fully transcribed on the same day, preferably right after its completion. The interviews occurred at the moment that the data became repetitive and achieved the objective of the research.

The instrument used during the interview was a semi-structured questionnaire consisting of two parts: the first with questions relating to the characterization of the interviewee (age, marital status, education, practice time in nursing and in the service under study) and the second with questions related to the perception of the nurse's role in emergency care service (In your opinion, what is the role of the nurse in the emergency room? Which activities the nurse must perform? Which ones should not perform?).

For data analysis, the content of the transcribed interviews was submitted to content analysis, thematic modality, followed by phases of pre-analysis, material exploration, processing of the results and interpretation. In the pre-analysis, speeches readings were performed to raise relevant points for the objective of the study. In the exploration phase of the material, it proceeded to the coding process, attributing codes to sense nucleus, representing the content expressed in the speeches and were aggregated into units. In the last phase, it was categorized consisting in the classification of elements according to their similarities and differentiation, with subsequent reassembly by common characteristics ${ }^{(14)}$.

The study was approved by the Standing Committee on Ethics in Human Research of the State University of Maringa (Opinion No. 747/2010). For the differentiation of subjects and preservation of their identity, codes were used. Nur. for nurses and Tec. for technical nursing followed by the number of the interview order.

\section{Results}

Among the 30 interviewed professionals, seven were nurses and 23 nursing technicians, most of them were female (25). The age ranged from 25 to 55 years old, with an average of 40 years. The average training time was 14 years, and 21 worked in the profession for over ten years.

From the content analysis emerged three categories, which express the perception of the nursing staff regarding the functions of nurses who work in emergency services, described below.

\section{Administrative and management functions of the nurse}

The speeches of the interviewees referred 
mostly to the nurse management functions. Particularly, the nurses demonstrated to recognize the importance of the management function and its balance with the direct care as a way to allow continued provision of patient care: The nurse must provide direct care to the patient, but also take care of the organization and administration of the service. To conciliate these two things is very important to plan the care and attend the needs of patients (Nur.02). The nurse should be involved in assistance and also perform the administrative part, with a balance between the two. From the moment they perform the assistance, they will also see what is being done, what can improve and how to make it (Nur.07).

However, particularly, some technical nursing does not seem to recognize the importance of management and administrative role performed by nurses for the continuity of patient care in emergency services: The nurse is concerned to fix the form and see if the patient is registered in the central beds. They should verify if we need help to provide care, as a nurse technician, which is more important. And in fact, care is their function (Tec.07). They perform only the paperwork, they have to pick up a book and write everything the patient has, they spend hours performing this (Tec.15). They have to do that book, during their duty, and we need help and they cannot leave because they have to pass the duty to another nurse (Tec.23).

It is noticed that technical professionals in nursing drew attention to the fact that nurses devote little attention to the staff and their needs in care. They also highlighted that care is nurse's role, referring only to the direct assistance and that this professional should help the staff in providing care.

\section{Leadership and supervision of staff as nurse's role}

In this category, it was noted that the speeches of nurses and nursing technicians were converging to emphasize that the activities related to leadership and supervision of the staff, nurse should perform the service organization, the sector, and distribution of tasks to be performed by different professionals. The opinions of staff members that converge on the positivity of leadership and supervision indicate that the performance of these functions culminates in the organization of the service and the direction of the actions, not allowing the staff to develop a disorderly assistance to the patient at risk. ...The nurse's role is leadership, is to command, to organize the service (Tec.08). To nurse should coordinate the staff, delegate tasks at the time of emergency care, all working with a common goal (Tec.17). The nurse must assume their paper as organizer and leader of the assistance if we do not distribute the functions; each one does what it wants. Thus, the service and patient care are not well performed. That's too bad, especially for the emergency service where the patient's life is at risk (Nur.01).

However, despite the nurse's functions relating to management, interviewees also mentioned the involvement of nurses in direct care, as shown below.

\section{Direct patient care as nurse's role}

Through the speeches, one can see that in this sector, not only the management staff is a nursing function, but also the direct care of critically ill patients. In this perspective, some professionals pointed out as prerogative activity of the nurse, in the emergency sectors, specific care, for example, performing invasive procedures: The most invasive procedures, such as urinary catheterization, is a nurse's role, as well as other more complex (Tec. 20). Nasogastric probe must be exclusive of nurses, and passing bladder catheter also (Nur. 23).

Other professionals mentioned that nurses are responsible for the implementation of Systematization of Nursing Care, which was understood as a way of providing care, as it allows patient evaluation and care planning, increasing the quality of care: The nurse must provide the direct patient care, including the nursing prescription, evolution, medical history, physical examination, all is responsibility of the nurse. It is a private function achieved through a good evaluation of the case (Nur.12). Nurses must take care of the critically ill patients directly; apply the Systematization of Nursing Care. This helps in the care and differentiates the practice of other professionals (Nur.6). The nurse serves to evaluate the patient thoroughly; they must be able to identify the problems and needs of the patient especially in urgency and emergency service, but this is only possible through the 
application of Systematization of Nursing Care (Tec.11).

It is noticed in the speech of Nur.6 that besides the importance of Systematization of Nursing Care, this instrument, specific nurse, marks an important difference in their professional performance to other members of the health staff.

Overall, the speech allowed understanding nurses roles in emergency services, the development of management activities, as well as the leadership and supervision of the nursing staff and direct care provided to seriously ill patients, aspects that are discussed in coordination in this work.

\section{Discussion}

The findings contribute to nurses reflect about their care and management practice in emergency services according to the perception of the nursing staff professionals and thus, can improve their performance in favor for the service, the staff and patients needs.

Among the functions of the emergency department nurse discussed in this research, it can be noted that the most recurrently cited were the management activities, leadership and supervision of staff and the execution of private activities such as invasive care and care planning.

Specifically about management activities, there was a difference in the speeches of nurses and nursing technicians. Although a portion of the technicians involved in the service has already completed the undergraduate degree in nursing, there is an implicit difficulty recognizing the responsibilities of nurses, especially those relating to the administrative function of this professional. Supposedly, this difficulty of the interior of the staff, resulting from the distance between manual labor and the management of care experienced by technician professional, mainly because the demand for labor in the emergency department in question, indeed, overwhelm the staff, which can generate an undervaluation of the administrative function and the oversizing of direct assistance function.

Furthermore, it must consider that there is a historic split in the nursing work between managing and caring, which permeates the profession to the present. This dilemma has its roots in the systematization of nursing knowledge, which since its inception has dissociation between theory and practice $^{(15)}$.

From this perspective, the administrative or management activities would be the organization of work and human resources in nursing, using means and instruments of various administrative knowledge, materials, equipment and facilities, in addition to the technical tools of management, such as: personnel dimensioning, planning, continued/permanent education, supervision, performance evaluation, which are used in order to create and implement adequate conditions for the production of care and nursing staff performance ${ }^{(16)}$.

It is noteworthy also that the management of assistance involves having focused on the care of professional actions, for example, by the staff organization and distribution of functions between the different professionals, as observed in this study. The nurse manages the care when plans it, or delegates or not, when foresees and provides resources, enables the nursing staff and interacts with other professionals, occupying spaces of articulation and negotiation towards the achievement of care improvements $^{(8)}$. Therefore, as reported by Nur.02, there is no possibility of care if there is no proper coordination of the care and administrative service, which constitute professional nursing functions.

Similarly, it was evidenced in the report of Nur.07 that, when exercising the management and administrative role the nurse assesses the care that is being provided to the patient and identify what still needs to improve or be made to attend the specific needs of each one. It should be recognized care as possible and needed focus to be managed within institutions in a dimension that goes beyond the technicality and incorporate the knowledge and 
attitudes of rational and sensitive order ${ }^{(15)}$.

In this perspective, nurses should seek new instruments to organize the work to promote the improvement of nursing care, for example, to organize and optimize their workforce, and the staff's one as a whole, with equitable divisions of the activities. Therefore, in urgent and emergency services, nurses, also, to participate directly in care, has the role in providing properly the unit, provide material and human resources, providing service organization that balances demand and necessary resources ${ }^{(1)}$.

In addition, time management is an essential skill that must be developed by nurses who work in emergency services because they must find time to perform or coordinate the daily care to critically ill patients, solving communication problems and interpersonal employee relationship, develop administrative actions required by the institution and still have time for unforeseen ${ }^{(8-9)}$. In this regard, we note the importance of recording the events that occurred during the period in the book of shift changes, which enables the service organization and the sector and, especially, the continuity in the provision of care to patients. However, it was noted in the statements of some nursing technicians that for them, the preparation of records for the change of shift book is unnecessary.

Registration mode on duty passage used by nurses in this service, in particular, gives staff members the idea of a bureaucratic activity and that takes time and nurse's attention, leading them to relegate the role of directly assist patients or to provide assistance to the nursing staff in this assistance. It is worth noting that in an attempt to ensure the provision of care; the change of shift procedure is used because it is a communicative activity and essential routine and inherent in the nurse's daily work, which allows organizing and planning the nursing interventions.

Therefore, the written record is not only a bureaucratic and institutional demand, but mostly, is a fundamental resource for information management and continuity of care being provided, as well as its evaluation ${ }^{(17)}$. Given that, amid the fast pace of the flow of patients and procedures, registration facilitates the resumption of the current state of the patient, with emphasis on complications and procedures performed during the period and those which should be performed in the following shifts, which can also contribute to the direction of the work of general nursing staff, and not just nurses.

However, the testimony of Tec.07, for example, highlights the negative perception that the management and administrative services mischaracterize the role of the nurse. However, it is believed that this perception may be related to the still fragmented view of managing and taking care directly of the patient, which are interconnected functions and contribute to comprehensive care.

Another function evidenced in this study as an assignment of the emergency department nurse is the leadership and supervision of staff. The leadership would be a role built by nurse figure next to other professionals, but according to the nursing staff becomes an expected role for nurses in this service. Thus, as found in the reports of Tec.08 and Nur.01 points out that the leading role assumed by nurses is essential to organize the service and quality of care. From this perspective, integrative review study about the nurse's leadership in urgent and emergency services suggests that the motivating and encouraging attitude of nurses and their communication skills are the aspects that positively influence the results of the assistance ${ }^{(18)}$. When the nurse performs a leading role in assisting, is building a favorable space for the development of its basic tasks, both administrative, as the health care and education.

About leadership, nurses should prioritize personal issues, interpersonal effectiveness, financial management and human resources. Furthermore, the management and leadership skills must be based on solid knowledge and professional experience of each nurse. Thus, relational and transformational leadership are needed to improve the satisfaction of the nursing staff and therefore, assistance to users ${ }^{(19)}$. 
This work is possible since there is an adequate view of what should be done for each one, dividing tasks between staff members and attention to the individual and collective responsibilities.

It should be noted, however, the absence of mention of the educational work of the nurse with the staff in the emergency unit. Although the leader staff role conducive to the development of educational practices, it was observed that these activities were not commonly associated with the role of nurses in the care delivered in urgent and emergency sectors. This may be related to the fact that educational activities in this institution are punctual and usually organized and conducted by the continuing education service, which can replace or even inhibit the nurse in the performance of a staff educator role.

It can also occur, that a significant proportion of nursing technicians, participants of this study and graduated (04 cases) or is studying nursing (03 cases), which may reinforce the idea that they do not need or do not perceive the initiatives of the nurse turned to the teaching-learning staff process. It is note also, that the work in public emergency service, marked by high urgent and emerging demands, overload work, overcrowding, human resources and materials insufficient and compromised quality of interpersonal relationships, negatively impact the staff work process, generates mishaps in development of the nurse's role, including formative role with the nursing staff and even as a tutor of undergraduate students and residents.

Another nurse's function pointed by the staff was the execution of private activities such as invasive and more complex procedures, and the use of Systematization of Nursing Care to guide assistance. The concomitant performance of complex care by nurses and nursing technicians to severely ill patients and Systematization of Nursing Care trivialization can reinforce the lack of recognition of the professional nurse within the staff. Although the functions of the nurse in the emergency department are theoretically well-defined, a study performed by 23 nurses in a hospital emergency department, points out that deficits in working conditions and the very fragmented characteristic of nursing care, cause discouragement, insecurity, and low staff performance, thus imposing barriers to the implementation and recognition of the expected functions of nurses ${ }^{(13)}$.

To nurses can build their identity in the field of assistance and demystify concepts and postures as the submission of the medical profession, it is necessary to abandon the use of interventions at random, without planning, scientific justification, and reflection. In this perspective, as evidenced by Tec.11, the use of Systematization of Nursing Care allows nurses to detect the needs and priorities of each patient, thus providing a direction for possible interventions. The incorporation of SNC to the nursing work dynamics implies in making quick decisions, risk assessment, priority setting and integral patient care, highlighting the importance of differential care performed by nurses during care ${ }^{(20)}$.

\section{Final Considerations}

The study results showed that the nursing staff, active in the emergency service, perceives as nurses functions, developing administrative and management activities, as well as the leadership and supervision of the nursing staff and the provision of direct care of the seriously ill patient. However, it is necessary to strengthen the need for nursing technicians do not dissociate the management function of the nursing care since the former is the mainstay of the planning and implementation of the second.

About the leader role, understood as a nurse's function according to interviewees, the technical point that the nurse organizes the service towards a common goal of the assistance. Also, the assistance function of nurses has a great value for the staff, especially when uses the Systematization of Nursing Care. 
We conclude that the nurse is working object, characterized by care and attending the needs of service users, is presented clearly and permeates in a common form of the speeches of interviewees. However, the roles of nurses in the work process, whose goal is the provided care, are still conflicting, from the perspective of the nursing team.

\section{Collaborations}

Barreto MS, Teston EF, Miranda JG and Arruda GO contributed to the work design, organization, analysis and interpretation of data, article writing and final approval of the version to be published. Valsecchi EASS and Marcon SS contributed to the design and orientation of the work, critical review and final approval of the version to be published.

\section{References}

1. Coelho MF, Chaves LDP, Anselmi ML, Hayashida M, Santos CB. Analysis of the Organizational Aspects of a Clinical Emergency Department: A Study in a General Hospital in Ribeirao Preto, SP, Brazil. Rev Latino-Am Enfermagem. 2010; 18(4):770-7.

2. Nugus P, Holdgate A, Fry M, Forero R, McCarthy S, Braithwaite J. Work Pressure and Patient Flow Management in the Emergency Department: Findings From an Ethnographic Study. Academic Emerg Med. 2011; 18(10):1045-52.

3. McHale P, Wood S, Hughes K, Bellis MA, Demnitz $\mathrm{U}$, Wyke S. Who uses emergency departments inappropriately and when - a national crosssectional study using a monitoring data system. BMC Med. 2013; 11(258):1-9.

4. Jorge VC, Barreto MS, Ferrer ALM, Santos EAQ, Rickli HC, Marcon SS. Equipe de enfermagem e detecção de indicadores de agravamento em pacientes de pronto-socorro. Esc Anna Nery. 2012; 16(4):767-74.

5. Souza MF, Figueiredo LA, Pinto IC. Análise da utilização do serviço de pronto-socorro na percepção do usuário. Cienc Cuid Saúde. 2010; 9(1):13-20.
6. Silva LG, Matsuda LM, Waidman MAP. The structure of a public emergency care service, from the workers' view: perspectives on quality. Texto Contexto Enferm. 2012; 21(2):320-8.

7. Silva, AP, Munari DB, Brasil VV, Chaves LDP, Bezerra ALQ, Ribeiro LCM. Trabalho em equipe de enfermagem em unidade de urgência e Emergência na perspectiva de Kurt Lewin. Cienc Cuid Saúde. 2012; 11(3):549-56.

8. Zambiazi BRB, Costa AM. Gerenciamento de enfermagem em unidade de emergência: dificuldades e desafios. Rev Adm Saúde. 2013; 15(61):169-76.

9. Sa MC, Azevedo CS. Subjetividade e gestão: explorando as articulações psicossociais no trabalho gerencial e no trabalho em saúde. Ciênc Saúde Coletiva. 2010;15(5):2345-54.

10. Mônica FC, Lucieli DPC, Maria LA, Miyeko H, Claudia BS. Analysis of the organizational aspects of a clinical emergency department: a study in a general hospital in Ribeirao Preto, SP, Brazil. Rev Latino-Am Enfermagem. 2010; 18(4):13-9.

11. Hoskins R. Evaluating new roles within emergency care: a literature review. Int Emerg Nurs. 2011; 19(3):125-40.

12. Considine J, Lucas E, Payne R, Kropman, Stergiou HE, Chiu H. Analysis of three advanced practice roles in emergency nursing. Australas Emerg Nurs J. 2012; 15(4)219-28.

13. Furtado BMASMF, Araújo Júnior JLC. Perception of nurses on working conditions in the emergency area of a hospital. Acta Paul Enferm. 2010; 23(2):169-74.

14. Bardin, L. Análise de conteúdo. 20ª ed. Lisboa: Edições 70; 2011.

15. Montezelli JH, Peres AM, Bernardino E. Demandas institucionais e de cuidado no gerenciamento de enfermeiros em um pronto socorro. Rev Bras Enferm. 2011; 64(2):348-54.

16. Santos JLG, Lima MADS. Gerenciamento do cuidado: ações dos enfermeiros em um serviço hospitalar de emergência. Rev Gaúcha Enferm. 2011; 32(4):695-702. 
17. Penaforte MHO, Martins MMFPS. The visibility of hygiene self-care in nurse-to-nurse shift change reports. Rev Latino-Am Enfermagem. 2011; 19(1):131-9.

18. Silva DS, Bernardes A, Gabriel CS, Rocha FLR, Caldana G. A liderança do enfermeiro no contexto dos serviços de urgência e emergência. Rev Eletr Enferm [periódico na Internet]. 2014 [citado 2015 out 10]; 16(1):211-9. Disponível em: https://www.fen.ufg.br/fen_revista/v16/n1/ pdf/v16n1a24.pdf
19. Soto-Fuentes P, Grandón KR, Santana DM, Yáñez OJ. Competencias para la enfermera/o en elámbito de gestión y administración: desafíos actuales de la profesión. Aquichan. 2014; 14(1):79-99.

20. Azevedo ALCS, Ana Paula Pereira AP, Lemos C, Coelho MF, Chaves LDP. Organização de serviços de emergência hospitalar: uma revisão integrativa de pesquisas. Rev Eletr Enf [periódico na Internet]. 2010 [citado 2015 jun. 12]; 12(4):736-45. Disponível em: http://www.fen.ufg.br/revista/ v12/n4/v12n4a20.htm. 